Article

\title{
Experimental Efficiency Analysis of a Photovoltaic System with Different Module Technologies under Temperate Climate Conditions
}

\author{
Slawomir Gulkowski *, Agata Zdyb and Piotr Dragan \\ Institute of Renewable Energy Engineering, Faculty of Environmental Engineering, Lublin University of \\ Technology, Nadbystrzycka 40B, 20-618 Lublin, Poland; a.zdyb@pollub.pl (A.Z.); piotr.dragan@wisznice.pl (P.D.) \\ * Correspondence: s.gulkowski@pollub.pl; Tel.: +48-81538-4654
}

Received: 30 October 2018; Accepted: 26 December 2018; Published: 3 January 2019

check for updates

Featured Application: This research contributes to guiding planners and investors in the sizing, locating and selection of module types for photovoltaic (PV) installations. It can be useful for the prediction of electric energy production by different PV technologies at high latitude under temperate climate conditions.

\begin{abstract}
This study presents a comparative analysis of energy production over the year 2015 by the grid connected experimental photovoltaic (PV) system composed by different technology modules, which operates under temperate climate meteorological conditions of Eastern Poland. Two thin film technologies have been taken into account: cadmium telluride (CdTe) and copper indium gallium diselenide (CIGS). Rated power of each system is approximately equal to $3.5 \mathrm{kWp}$. In addition, the performance of a polycrystalline silicon technology system has been analyzed in order to provide comprehensive comparison of the efficiency of thin film and crystalline technologies in the same environmental conditions. The total size of the pc-Si system is equal to $17 \mathrm{kWp}$. Adequate sensors have been installed at the location of the PV system to measure solar irradiance and temperature of the modules. In real external conditions all kinds of modules exhibit lower efficiency than the values provided by manufacturers. The study reveals that CIGS technology is characterized by the highest energy production and performance ratio. The observed temperature related losses are of the lowest degree in case of CIGS modules.
\end{abstract}

Keywords: photovoltaic systems; thin film modules; performance assessment; PV efficiency

\section{Introduction}

The European Directive (EU) 2015/1513 amending Directive 2009/28/EC on the promotion of the use of energy from renewable sources sets a binding target of $20 \%$ final energy consumption in EU from renewable sources by 2020 [1,2]. One of the renewable energy systems (RES) is solar energy which can be utilized in photovoltaic (PV) systems that are non-polluting and do not generate greenhouse gases or wastes which have to be stored. This kind of system has no moving parts, so the maintenance cost is very little [3,4]. Due to its advantages, photovoltaic (PV) energy production has experienced a rapid growth all over the world in recent years, and, according to the policies of particular countries, a number of photovoltaic (PV) power plants increases [5-9].

Producers of PV modules provide characteristic parameters measured under Standard Test Conditions (STC) which are defined as follows: solar irradiance $G=1000 \mathrm{~W} / \mathrm{m}^{2}$, module temperature $25^{\circ} \mathrm{C}$, AM 1.5, and wind speed less than $5 \mathrm{~m} / \mathrm{s}$. The testing measurements are usually made in laboratories with the use of solar simulators. Under real conditions, the results of PV performance can 
be different because of the influence of specific environmental parameters in the given location [10], such as global solar radiation intensity and spectrum [11], ambient temperature, relative humidity, wind speed, and dust concentration in the air [12-17]. All these factors strongly depend on meteorological conditions, characteristic for given climate [18,19]. Moreover, it is important that the influence of environmental conditions is complex and final energy production depends on the overlapping of several effects, which are difficult to analyze individually [20]. In general, the most important factors are solar irradiation and temperature, since they directly influence the energy production, and PV modules temperature, which affects modules efficiency. For this reason, outdoor analysis of daily and seasonal variations of PV module performance allow the energy production to be realistically estimated and also limit the over or under sizing in prospective plants.

In recent years much research on outdoor measurements of PV systems has been done, but the majority of them refer to warm climate conditions [21-23]. Nonetheless, spreading of PV technology all over the world implies the need for this kind of study also in locations characterized by lower insolation level such as temperate climate [24,25].

It is also worth noting that most of work on outdoor photovoltaic (PV) performance is devoted to the investigation of pc-Si technology, since this is the one which is the most popular on the PV market. However, the dropping price of thin film technology (e.g., a-Si, CdTe, CIGS) is a motivation to testing of various kinds of thin film solar modules under real external conditions. The following types of PV technologies were studied experimentally under different climatic conditions:

- $\quad$ a-Si, HIT, mc-Si-India [26],

- $\quad$ a-Si, HIT, pc-Si-India [27],

- a-Si, c-Si, CdTe-Turkey [5],

- $\quad$ mc-Si-Greece [2],

- $\quad$ mc-Si, pc-Si, a-Si, CIGS, CdTe-Italy [28],

- $\quad c-S i$, a-Si, HIT-Italy [29],

- mono-Si, CIS-Turkey [30],

- a-Si, c-Si, CIGS-United Kingdom [11],

- $\quad$ a-Si, c-Si, CIGS, CdTe-Germany [31],

- mono-Si, poli-Si, a-Si, CIGS, CIS, CdTe-Netherlands [20].

All these investigations add new knowledge about the influence of external conditions on solar modules built with different semiconductor materials and allow for selecting the best technology type in the given location. At present, there are no published results of this kind of comparative study carried out in the Polish climate. Thus, the goal of this work is to characterize the solar conditions in Poland and evaluate the outdoor performance of three different PV technologies at the same location. This paper presents the comparison of traditional polycrystalline silicon (pc-Si) PV technology and two thin film technologies: cadmium telluride (CdTe) and copper-indium-gallium-diselenide (CIGS).

Monthly solar irradiation at the given location has been calculated and the energy yield for each type of PV technology has been compared. Daily efficiency and average yield, as well as direct current (DC) performance ratio, have been calculated and analyzed. The effects of the temperature on performance of different studied PV technologies have been also investigated, since the relevance of temperature as the parameter affecting modules efficiency depends on the type of semiconductor materials used. The attempt has been made to discuss the obtained results with research performed in other places under similar climate conditions.

\section{Methodology}

\subsection{Experimental Photovoltaic Installation}

The experimental PV installation consisted of different, fully commercial modules located in the East of Poland (Latitude $51^{\circ} 51$ and Longitude $23^{\circ} 10$ ) is shown in Figure 1. Technologies of 
the modules used in the analysis and their nominal power were as follows: cadmium telluride $(3.3 \mathrm{kWp})$, copper-indium-gallium-diselenide $(3.72 \mathrm{kWp})$, and polycrystalline silicon $(17 \mathrm{kWp})$. Detailed specification of each kind of module based on the PV manufacturer data sheet is presented in Table 1. The modules are oriented to the south and tilted at the optimum angle for the given latitude equal to $34^{\circ}$. The installation is connected to the grid using the inverters. Both thin film installations are connected with the use of inverters with one maximum power point tracker (MPPT), while for pc-Si PV string the inverter equipped with two MPPT systems is used. The distance between the rows of panels equals to $6.3 \mathrm{~m}$.

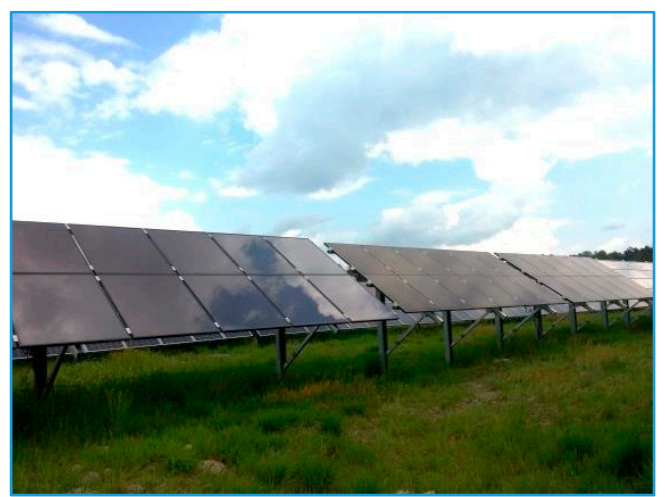

Figure 1. Experimental installation consisting of different PV (photovoltaic) module technologies.

Table 1. PV modules specification data.

\begin{tabular}{ccccc}
\hline PV Technology & $\boldsymbol{P}_{\max }[\mathrm{W}]$ & Area $\left[\mathbf{m}^{2}\right]$ & $\begin{array}{c}\text { Temp. Coefficient } \\
\text { of } \boldsymbol{P}_{\text {max }} \boldsymbol{\beta}\left[\boldsymbol{\beta}{ }^{\circ} \mathbf{C}\right]\end{array}$ & Efficiency $\boldsymbol{\eta}_{\boldsymbol{r}}[\%]$ \\
\hline Cadmium telluride (CdTe) & 75 & 0.72 & -0.25 & 10.6 \\
$\begin{array}{c}\text { Copper indium gallium } \\
\text { diselenide (CIGS) }\end{array}$ & 155 & 1.25 & -0.31 & 12.6 \\
Polycrystalline silicon (pc-Si) & 250 & 1.55 & -0.4 & 15.4 \\
\hline
\end{tabular}

At the location of the experimental system, solar radiation intensity on PV module plane, as well as the temperature of the modules, were measured. A solar radiation sensor based on the monocrystalline silicon solar cell is located in the centre of the installation and tilted at the same angle as the modules. Pt1000 resistance temperature detectors are attached to the back of the module. Detailed specification of the devices used is listed in Table 2.

Table 2. Specification of the devices used for irradiance and temperature measurements.

\begin{tabular}{cc}
\hline Solar Radiation Sensor & Temperature Sensor \\
\hline Monocrystalline silicon cell $(5 \times 3.3 \mathrm{~cm})$ & \\
Temperature range: $-20^{\circ} \mathrm{C}$ to $+70{ }^{\circ} \mathrm{C}$ & Range: $-40{ }^{\circ} \mathrm{C}-70{ }^{\circ} \mathrm{C}$ \\
Radiation range: 0 to max. $1400 \mathrm{~W} / \mathrm{m}^{2}$ & \\
Tolerance of the irradiance sensor: $+/-5 \%$ & \\
\hline
\end{tabular}

Inverters, as well as both mentioned sensors, were connected to the central data-logging computer system for synchronous data collection. All parameters, such as solar irradiance, DC generated electric power, and module temperature of each PV technology studied were measured at each 5 min during the considered year of 2015 and stored for the analysis. All necessary computations were carried out with the use of Matlab/Simulink software (MathWorks, Natick, MA, USA). 


\subsection{Methods of Experimental Data Analysis}

Calculations for performance evaluation of PV modules were carried out according to the International Electrotechnical Commission standard IEC 61724-1 [32]. The daily energy $\left(E_{D C}^{d}\right)$ produced by each technology PV array was calculated from the following equation:

$$
E_{D C}^{d}=\sum_{\text {sunrise }}^{\text {sunset }} P_{D C}^{d}(t) \cdot \Delta t
$$

where: $\Delta t$-time step of measurements $(5 \mathrm{~min}), P_{D C}^{d}(t)$ - power generated at a particular time of the day measured as a product between the current and the voltage at the inverter inlet.

Daily irradiation was calculated on the basis of irradiance $G\left(\mathrm{~W} / \mathrm{m}^{2}\right)$ according to the formula:

$$
H^{d}\left(\frac{\mathrm{kWh}}{\mathrm{m}^{2} \cdot \mathrm{day}}\right)=\sum_{\text {sunrise }}^{\text {sunset }} G(t) \cdot \Delta t
$$

where $G(t)$-irradiance measured at a particular time $t$ of the day.

The effect of the differences in energy production caused by different size of installation of each technology array was eliminated by dividing the daily DC energy production $\left(E_{D C}^{d}\right)$ by the nominal power output of the installation at STC $\left(P_{M}^{S T C}\right)$. The daily yield is given by the ratio between daily energy produced by each technology PV array and output peak power $P_{M}^{S T C}$ of the modules under STC:

$$
Y^{d}(\mathrm{kWh} / \mathrm{kWp})=\frac{E_{D C}^{d}}{P_{M}^{S T C}}
$$

The effect of insolation can be expressed by reference yield $Y_{R}^{d}$, which is defined as the ratio of daily irradiation and irradiance at STC according to the formula:

$$
Y_{R}^{d}=\frac{H^{d}}{G^{S T C}}
$$

where: $H^{d}$-daily irradiation expressed in $\mathrm{kWh} / \mathrm{m}^{2}, G^{S T C}$-irradiance under standard test conditions (in $\mathrm{kW} / \mathrm{m}^{2}$ ).

For an ideal PV system operating under STC, the calculations based on the Equations (3) and (4) should provide the same results. Nonetheless, the power losses in the PV system (modules and other particular components) lead to lowering of the $Y^{d}$ value in comparison with $Y_{R}^{d}$. In order to evaluate real energy production relation to the ideal scenario, performance ratio (PR) of the system was calculated:

$$
P R=\frac{Y^{d}}{Y_{R}^{d}} .
$$

Another parameter used for the assessment of real performance of the modules was efficiency, defined as a quotient between the energy production in reference period and solar irradiation received by the module:

$$
\eta=\frac{E_{D C}^{d}}{H^{d} \cdot \text { Area }} \cdot 100 \%,
$$

where Area is the total area of the modules.

\section{Results}

Monthly irradiation on the module plane at the considered location, in a warm summer continental climate according to Köppen's climate classification, is shown in Figure 2. As can be seen, the most sunny period, beneficial for energy production from photovoltaics, was June to August in 2015. There are significant differences in the irradiation level in plane of module during the year: from a minimum 
of $20 \mathrm{kWh} / \mathrm{m}^{2}$ in January to a maximum of $191 \mathrm{kWh} / \mathrm{m}^{2}$ registered in August. The monthly average daily irradiation on module plane ranged from only $0.67 \mathrm{kWh} / \mathrm{m}^{2}$ in January to $6.18 \mathrm{kWh} / \mathrm{m}^{2}$ in August. In general, about $80 \%$ of yearly solar irradiation in Poland is received during the sunny and warm half of the year, from April to August.

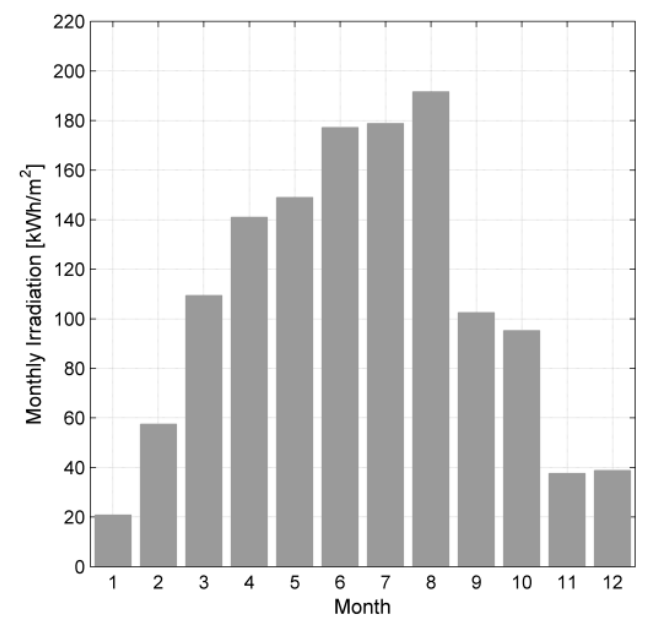

Figure 2. Monthly irradiation on module plane measured in 2015.

In order to better explain the on-site solar irradiance conditions, Figure 3 shows the accumulated irradiance distribution of incident global irradiation measured for period under study. As can be seen, irradiance conditions characterized by low values were the most frequent ones, resulting in median equal to $193 \mathrm{~W} / \mathrm{m}^{2}$. About $36 \%$ of the measurements have an irradiance lower than $100 \mathrm{~W} / \mathrm{m}^{2}$ and almost $98 \%$ of registered values are below $1000 \mathrm{~W} / \mathrm{m}^{2}$, however, about $17 \%$ of the results were characterized by a good or very good irradiance conditions, which varied from $700 \mathrm{~W} / \mathrm{m}^{2}$ to $1200 \mathrm{~W} / \mathrm{m}^{2}$.

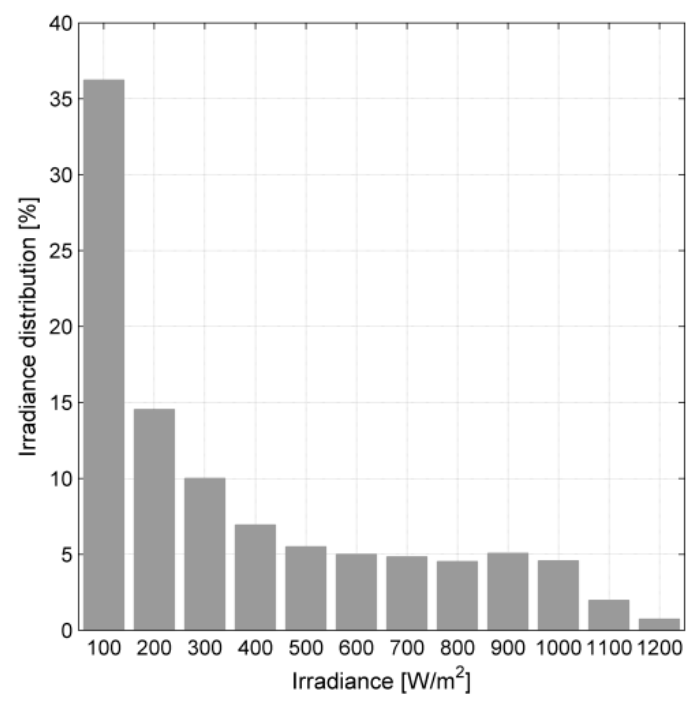

Figure 3. Accumulated percentage of collected incident global irradiation distribution according to irradiance levels measured in 2015.

Simultaneously to irradiance measurements, the temperature of the modules was monitored in the given location (Figure 4). The values of temperature of the modules depend mainly on the irradiation and ambient temperature and have a great impact on the efficiency of the modules. Registered values of the modules temperature varied from about $0{ }^{\circ} \mathrm{C}$ in cloudy winter days to $60{ }^{\circ} \mathrm{C}$ in summer sunny days. The median of the module temperature for the studied period is equal to $30^{\circ} \mathrm{C}$. 


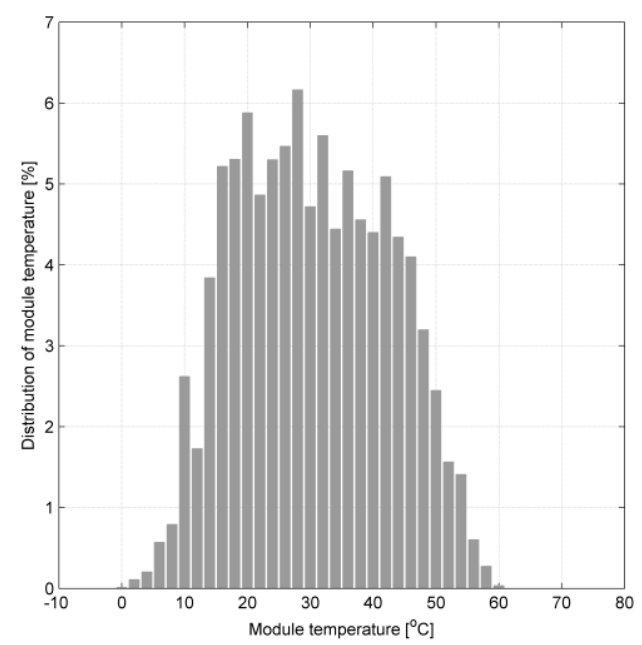

Figure 4. Percentage distribution of module temperature measured in 2015.

The obtained results (Figures 2-4) indicate that due to seasonal variations, in considered location under moderate climate, STC used by manufacturers are rarely met. Only a small portion of instantaneous irradiance measurements are around $1000 \mathrm{~W} / \mathrm{m}^{2}$ and module temperature values quite often reach $15-48{ }^{\circ} \mathrm{C}$ in the analyzed period.

An example of a hot sunny day, characterized by the high solar irradiance level reaching $1000 \mathrm{~W} / \mathrm{m}^{2}$ when the modules are heated by solar radiation up to $55{ }^{\circ} \mathrm{C}$, shows that under this kind of real conditions, the power generated by pc-Si installation is lower compared to thin film technologies (Figure 5).

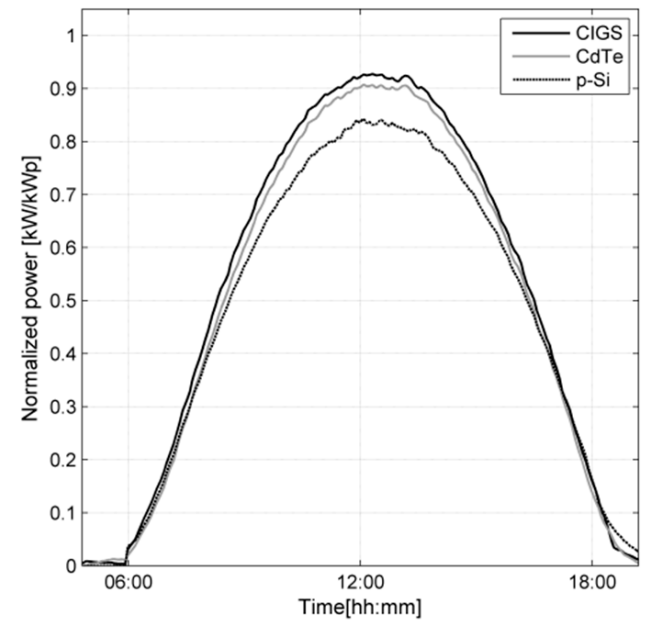

Figure 5. Normalized DC power generated by the PV systems of each studied technology. Maximum irradiance and temperature recorded for that day were $1000 \mathrm{~W} / \mathrm{m}^{2}$ and $55^{\circ} \mathrm{C}$, respectively.

For different analyzed PV technologies, the dependency of daily energy output as a function of daily average module temperature was shown in Figure 6. The increase of modules temperature caused by high incident solar irradiance during sunny days results in the decrease of energy production for all investigated technologies. As can be seen, thin film modules exhibit higher energy yield values than polycrystalline silicon ones. In particular, CIGS modules were characterized by the highest energy production in these specific-high temperature-conditions. The difference in daily energy production between CIGS and pc-Si modules during summer sunny days varies from $3.7 \%$ to $8.4 \%$, while the CdTe modules produced from $1.7 \%$ to $6.1 \%$ more energy than pc-Si modules. The reason why CIGS installation exhibits better performance on sunny days can be explained as a result of double effect. Firstly, the temperature coefficient of power is lower than in case of pc-Si modules. Secondly, power 
gains due to spectral effects reported in the literature, being those gains for CIGS technology more remarkable at high latitudes in the north Hemisphere, as in the case of Reference [31].

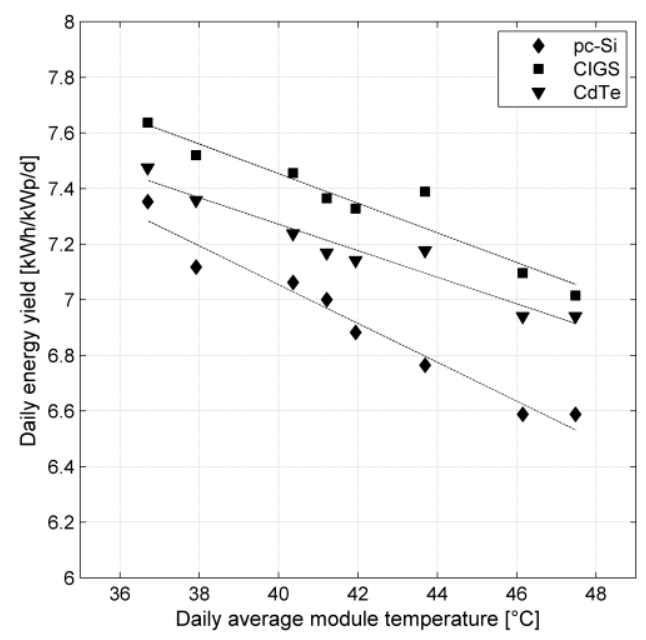

Figure 6. Daily energy yield vs. daily average temperature of the different technology modules calculated for sunny summer days of 2015 with similar solar irradiation levels.

Furthermore, CdTe modules, because of the lower power temperature coefficient and characteristic for this technology in high latitudes spectral gain in summer, have a better response than pc-Si, as shown in Figure $6[31,33]$. Nevertheless, the efficiency of CdTe modules is lower, and, finally, their yield is not as good as CIGS technology but better than pc-Si.

Experimental efficiency of each studied PV technology calculated as the average of daily efficiencies (Equation (6)) measured over the period February 2015-November 2015 can be seen in Figure 7. Efficiencies of pc-Si, CIGS and CdTe technologies were found to be $14.5 \%, 11.0 \%$, and $8.7 \%$, respectively. The results of calculations based on experimental data indicate lower efficiency values for all considered PV technologies in comparison to those obtained under STC presented in manufacturer datasheet (Table 1). The highest difference (17.9\%) was noted for CdTe technology. In the case of CIGS and pc-Si technologies, these differences were found to be $12.7 \%$ and $5.8 \%$ respectively.

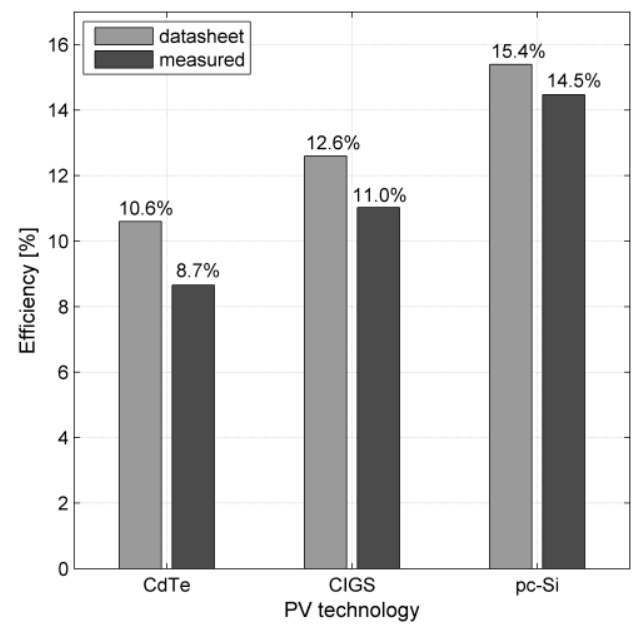

Figure 7. Comparison of the photovoltaic (PV) modules' efficiencies presented in manufacturer datasheet with the efficiencies obtained experimentally over the period February 2015-November 2015.

Analysis of daily energy efficiency calculated for chosen sunny days of 2015 with relatively high solar irradiation level (winter sunny days are characterized by lower values of solar irradiation in comparison with summer sunny days), presented in Figure 8, shows the linear decrease of daily 
efficiency with the increase of the daily average modules temperature. Temperature coefficients of efficiency for studied types of PV technology were derived from experimental data according to the following equation [34]:

$$
\eta=\eta_{r}-\mu\left(T_{c}-T_{r}\right),
$$

in which: $\eta_{r}$-reference module efficiency at reference temperature $T_{r}=25{ }^{\circ} \mathrm{C}, \mu$-temperature coefficient, $T_{c}$-measured temperature of the module. The temperature coefficient value is a slope of a line that represents the efficiency changes for each module type in Figure 8. The values of temperature coefficient, both obtained from experimental data and calculated based on manufacturer information (Table 1) as $\mu=\beta \eta_{r}$, are presented in Table 3.

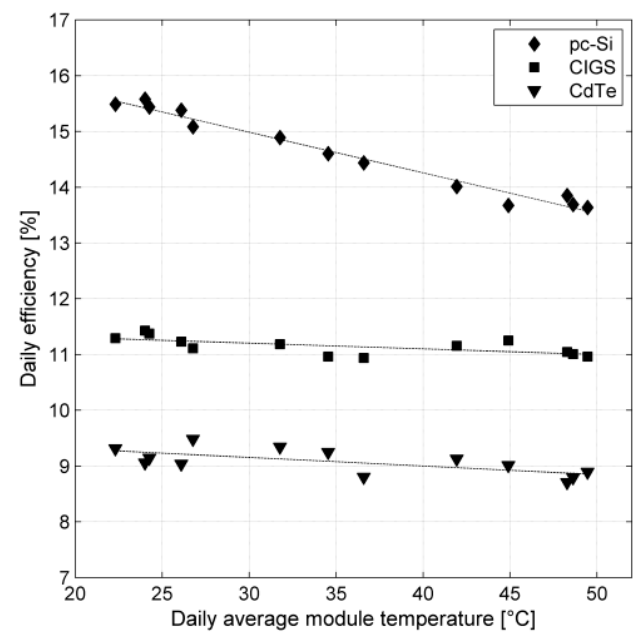

Figure 8. Effect of the module temperature on daily efficiency of each PV technology calculated for a chosen sunny day of 2015.

Table 3. Calculated and experimental values of the modules temperature coefficient.

\begin{tabular}{ccc}
\hline Photovoltaic (PV) Technology & $\begin{array}{c}\text { Temperature Coefficients } \\
\text { Calculated According to } \\
\text { Manufacturer Data } \\
{\left[\% /{ }^{\circ} \mathrm{C}\right]}\end{array}$ & $\begin{array}{c}\text { Temperature Coefficients } \\
\text { Obtained Basing on } \\
\text { Experimental Data } \\
{\left[\% /{ }^{\circ} \mathrm{C}\right]}\end{array}$ \\
\hline Cadmium telluride (CdTe) & 0.0265 & 0.0152 \\
Copper indium gallium diselenide (CIGS) & 0.0391 & 0.0102 \\
Polycrystalline silicon (pc-Si) & 0.0616 & 0.0728 \\
\hline
\end{tabular}

The comparison of the data obtained by two methods shows that the temperature coefficient resulting from experimental data exhibits a higher value for pc-Si modules than the value calculated according to the datasheet. The experimentally estimated value of pc-Si modules temperature coefficient is the highest compared to other technologies, which is directly connected to the strong influence of temperature on pc-Si energy production (Figure 6). The temperature coefficients of both thin film technologies are lower than these for pc-Si. In realistic operational conditions, their temperature coefficients achieve even lower values than the values determined from the datasheet, which is favorable and confirms the observations of high energy production by these technologies presented in Figure 6.

Figure 9 shows the dependency of DC output power on the PV modules temperature under real outdoor conditions for selected sunny days of 2015. The effect was determined by measuring DC output power and instantaneous module temperature at incident solar irradiance equal to $1000 \mathrm{~W} / \mathrm{m}^{2}$ $(+/-0.6 \%)$. The lowest module temperature at irradiance of $1000 \mathrm{~W} / \mathrm{m}^{2}$ was found to be $28{ }^{\circ} \mathrm{C}$ (registered at 11.18 on 23rd of March 2015). The highest value was equal to $49^{\circ} \mathrm{C}$ (registered at 12.09 on 2nd of July 2015). Experimentally obtained power was compared with the maximum power point 
(MPP) value at $25{ }^{\circ} \mathrm{C}$, taken from the manufacturer datasheet. Calculated results depict a strong dependency of output power on the temperature only for pc-Si modules. The variation of output power for pc-Si technology modules is around $18 \mathrm{~W}(7 \%)$ with the increase of temperature from $28^{\circ} \mathrm{C}$ to almost $50{ }^{\circ} \mathrm{C}$. In terms of thin film modules, the decrease of power with temperature is much smaller $(0.2-2.0 \%)$.

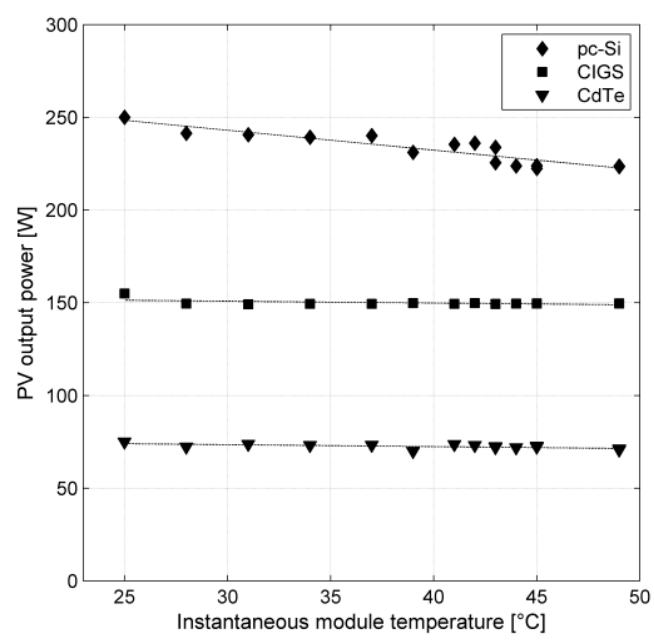

Figure 9. Photovoltaic (PV) output power of the different technology modules measured at $1000 \mathrm{~W} / \mathrm{m}^{2}$ vs. instantaneous temperature of the module.

The daily average energy yield of $1 \mathrm{kWp}$ of each technology is presented in Figure 10. The shape of the energy yield profile is similar to the shape of irradiation profile for the studied year, as shown in Figure 2. The highest energy production was noticed in summer months for all technologies due to the best irradiance conditions. During the summer period (June-August) CIGS modules produced about 3\% more energy than polycrystalline Si modules, which is in agreement with observations of temperature influence in this period. CdTe modules exhibit the lowest energy production, even in summer, in spite of the small value of temperature coefficient. Energy production by CdTe technology is lower in comparison with pc-Si of $1.1-8.9 \%$ which is probably caused by its small efficiency. An exception is June, when CdTe produced $0.2 \%$ more energy per kWp than pc-Si.

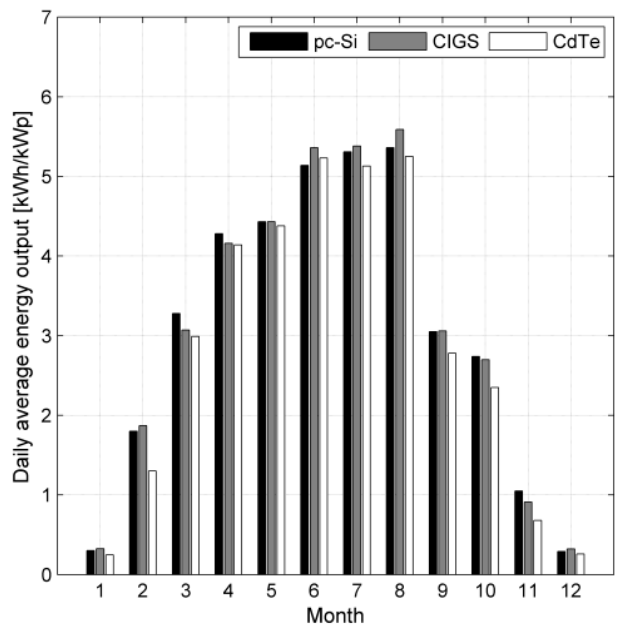

Figure 10. Comparison of daily average energy yield of each technology modules in 2015.

Monthly performance ratio (PR) calculated for each studied module technology is shown in Figure 11. PR values of CIGS array were found to be higher than that of pc-Si (from $2.5 \%$ in June to $3.5 \%$ in August). Higher energy yield and performance ratio of pc-Si modules were noticed in colder 
period of the year, i.e., from March to May (up to $4.8 \%$ ), and from October to November (up to $4.6 \%$ ). In terms of CdTe modules, lower monthly PR values were noticed in comparison to pc-Si technology for the whole year (from about 1\% in May to even 14\% in October), with the exception of June. During winter (December-February) PR values drop significantly due to occurrence of snow cover and decrease of inverters' efficiency at low input power levels. These two problems make it difficult to interpret the PR results obtained in winter, and thereby to assess the particular PV technologies in this period. Most of the months (March-October) are characterized by better insolation (Figure 2) and PR value above $80 \%$ (even $90 \%$ for pc-Si)

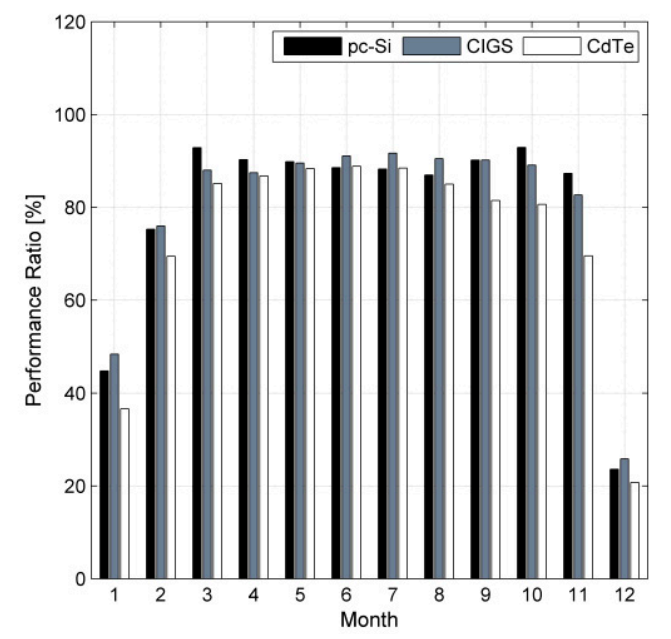

Figure 11. Comparison of calculated monthly performance ratio (PR) of each technology of the modules.

\section{Discussion}

The performance of solar modules depends on real external conditions, which is clearly visible in the results presented in this work, based on the measurements collected under temperate climate which is characterized by significant changes in both daily and yearly insolation and temperature. The role of solar radiation intensity on charge carriers generation and parameters of PV cells is direct and obvious. Nonetheless, it is worth remembering that most of the radiation absorbed by the cells is not converted into electricity, but it increases their temperature, thereby reducing the efficiency.

The influence of the temperature on the performance of solar modules, revealed in the presented experimental results, is different for various types of modules, since they are built with different semiconductors materials. In general, the semiconductor bandgap should correlate well with the solar radiation spectrum to achieve its maximum absorption. The optimum value of the bandgap, within the range of 1.0-1.6 eV results in good efficiency, which is observed even for single solar cells [35]. Temperature increase leads to narrowing of the semiconductor bandgap and also the intensification of recombination processes, in which current carriers disappear.

The bandgaps of the semiconductors used in the studied modules were different: $1.1 \mathrm{eV}$ for polycrystalline silicon, the material with a crystalline fraction of over $95 \%$, and $1.45-1.5 \mathrm{eV}$ in case of cadmium telluride [36-38]. Copper indium gallium selenide (CIGS) is a solid solution characterized by a higher bandgap value of around 1.04-1.68 eV, which depends on the exact composition of the material [39]. In the presented investigations, the role of the bandgap value is thus visible since the use of wider bandgap semiconductors extend their operational temperature [40]. The broader bandgap of CIGS may result in better resistance of this material to temperature increase.

The comparison of the presented results with studies conducted by other authors is rather difficult, even taking into account investigations performed at similar latitude, since the technical parameters of the modules and other devices differ, as do weather conditions in summer and winter. Exemplary studies performed in the UK show better performance of CIGS in winter due to the spectrum [11]. The investigations focused on the assessment of the spectral impact on different PV technologies, 
performed in Germany [31], indicate spectral gains of $2.4 \%$ for CdTe, $1.1 \%$ for c-Si (that can be compared with pc-Si), and $0.6 \%$ for CIGS during the entire year. Temperature coefficients of power estimated in the Netherlands for different PV technologies are higher than technical data for CdTe and CIGS and similar for poly-Si [20]. Considering the results of the investigations in the mentioned countries, it is worth remembering that the weather conditions in both winter and summer differ from those in Poland in spite of similar latitude.

In general, all kinds of modules in the analyzed solar plant of the whole nominal power of 1.4 MWp produced 1530.23 MWh in the entire 2015 year. This achieved result is remarkable, considering the role of the climatic zone in which the PV plant is situated, however, further long-term measurements are necessary. The degradation process of modules has to be observed and taken into account in long term comprehensive assessment. All kinds of modules are sensitive to some external factors, such as humidity that leads to the failure of electric parts, snow, dust and other pollutions that cause hot spot appearance, and even damage of the modules [41,42]. However, it is also worth emphasizing that external conditions influence particular types of modules in different ways, since the construction of the traditional and thin film modules is not the same. Internal processes in various semiconductor materials also contribute to the degradation.

\section{Conclusions}

The performance of three different PV technologies was characterized under moderate climate of Eastern Europe, in which about $80 \%$ of irradiation in plane of module is received in the warm half of the year. In this kind of climate, both standard test conditions (STC) and nominal operating cell temperature (NOCT) are not met, since only a small portion of irradiance achieves values within the range $800-1000 \mathrm{~W} / \mathrm{m}^{2}$. Module temperature is distributed around $30^{\circ} \mathrm{C}$.

Under this kind of external conditions, daily and monthly energy efficiency calculations revealed its lower values in comparison to efficiency measured under STC for each type of modules. The difference in normalized energy production among three studied PV technologies as well as the decrease of energy output with the increase of module temperature were shown. The highest impact of the temperature on generated power was registered in the case of pc-Si installation compared to thin film. CIGS and CdTe modules exhibit high resistance to temperature rise, which is indicated by temperature coefficients whose experimentally obtained values are even lower than the values based on the manufacturer data. On hot summer days, CIGS installation produced more energy than the polycrystalline one. Daily average yield, as well as the performance ratio of each technology installation, also indicated better performance of CIGS technology during summer months.

The presented results thus indicate that under temperate climate operating conditions, CIGS thin film technology is a valuable alternative to popular pc-Si.

Author Contributions: Conceptualization, S.G. and A.Z.; Data curation, P.D.; Formal analysis, A.Z.; Investigation, P.D.; Methodology, S.G.; Software and computing, S.G.; Supervision, A.Z.

Funding: This work was supported by Polish Ministry of Science and Higher Education. The solar plant was partially financed by EU project RPLU.06.02.00-06-086/12-00.

Acknowledgments: Authors would like to thank José Vicente Muñoz Diez and Gustavo Nofuentes Garrido from University of Jaén, Spain for valuable discussion.

Conflicts of Interest: The authors declare no conflict of interest.

\section{References}

1. Directive (EU) 2015/1513 of the European Parliament and of the Council of 9 September 2015 Amending Directive 2009/28/EC on the Promotion of the Use of Energy from Renewable Sources. Available online: http://data.europa.eu/eli/dir/2015/1513/oj (accessed on 20 December 2018). 
2. Gaglia, A.G.; Lykoudis, S.; Argiriou, A.A.; Balaras, C.A.; Dialynas, E. Energy efficiency of PV panels under real outdoor conditions-An experimental assessment in Athens, Greece. Renew. Energy 2017, 101, 236-243. [CrossRef]

3. Dale, M. A comparative Analysis of Energy Costs of Photovoltaic, Solar Thermal, and Wind Electricity Generation Techniques. Appl. Sci. 2013, 3, 325-337. [CrossRef]

4. Rehman, S.; El-Amin, I. Performance evaluation of an off-grid photovoltaic system in Saudi-Arabia. Energy 2012, 46, 451-458. [CrossRef]

5. Ozden, T.; Akinoglu, B.G.; Turan, R. Long term outdoor performances of three different on-grid PV arrays in central Anatolia-An extended analysis. Renew. Energy 2017, 101, 182-195. [CrossRef]

6. Raugei, M.; Frankl, P. Life cycle impacts and costs of photovoltaic systems: Current state of the art and future outlooks. Energy 2009, 34, 392-399. [CrossRef]

7. Dinçer, F. The analysis on photovoltaic electricity generation status, potential and policies of the leading countries in solar energy. Renew. Sustain. Energy Rev. 2011, 15, 713-720. [CrossRef]

8. Olchowik, J.M.; Dragan, P.; Gembarzewski, O.; Gulkowski, S.; Szymczuk, D.; Tomaszewski, R. The Reasons of the Delays in Introducing in Poland Law Regulations Favorable for Photovoltaics. In Proceedings of the 28th EUPVSEC, Paris, France, 30 September-4 October 2013; pp. 4676-4679.

9. Olchowik, J.M.; Cieslak, K.; Gulkowski, S.; Mucha, J.; Sordyl, M.; Zabielski, K.; Szymczuk, D.; Zdyb, A. Progress of development of PV systems in South-Eastern Poland. In Proceedings of the 35th IEEE Photovoltaic Specialists Conference, Honolulu, HI, USA, 20-25 June 2010.

10. Canete, C.; Carretero, J.; Sidrach-de-Cardona, M. Energy performance of different photovoltaic module technologies under outdoor conditions. Energy 2014, 65, 295-302. [CrossRef]

11. Gottschalg, R.; Betts, T.R.; Eeles, A.; Williams, A.R.; Zhu, J. Influences on the energy delivery of thin film photovoltaic modules. Sol. Energy Mater. Sol. Cells 2013, 119, 169-180. [CrossRef]

12. Kaldellis, J.K.; Kokala, A. Quantifying the decrease of the photovoltaic panels' energy yield due to phenomena of natural air pollution disposal. Energy 2010, 35, 4862-4869. [CrossRef]

13. Kaldellis, J.K.; Kapsali, M. Simulating the dust effect on the energy performance of photovoltaic generators based on experimental measurements. Energy 2011, 36, 5154-5161. [CrossRef]

14. Skoplaki, E.; Palyvos, J.A. On the temperature dependence of photovoltaic module electrical performance: A review of efficiency/power correlations. Sol. Energy 2009, 83, 614-624. [CrossRef]

15. Schwingshackl, C.; Petitta, M.; Wagner, J.E.; Belluardo, G.; Moser, D.; Castelli, M.; Zebisch, M.; Tetzlaff, A. Wind effect on PV module temperature: Analysis of different techniques for an accurate estimation. Energy Procedia 2013, 40, 77-86. [CrossRef]

16. Tanesab, J.; Parlevliet, D.; Whale, J.; Urmee, T. Seasonal effect of dust on the degradation of PV modules performance deployed in different climate areas. Renew. Energy 2017, 111, 105-115. [CrossRef]

17. Olchowik, J.M.; Gulkowski, S.; Cieslak, K.; Banas, J.; Jozwik, I.; Szymczuk, D.; Zabielski, K.; Mucha, J.; Zdrojewska, M.; Adamczyk, J.; et al. Influence of temperature on the efficiency of monocrystalline silicon solar cells in the South-eastern Poland conditions. Mater. Sci.-Pol. 2006, 24, 1127-1132.

18. Huld, T.; Gottschalg, R.; Beyer, H.G.; Topič, M. Mapping the performance of PV modules, effects of module type and data averaging. Sol. Energy 2010, 84, 324-338. [CrossRef]

19. Makrides, G.; Zinsser, B.; Phinikarides, A.; Schubert, M.; Georghiou, G.E. Temperature and thermal annealing effects on different photovoltaic technologies. Renew. Energy 2012, 43, 407-417. [CrossRef]

20. Louwen, A.; de Waal, A.C.; Schropp, R.E.I.; Faaij, A.P.C.; van Sark, W.G.J.H.M. Comprehensive characterization and analysis of PV module performance under real operating conditions. Prog. Photovolt. Res. Appl. 2017, 25, 218-232. [CrossRef]

21. Fuentes, M.; Nofuentes, G.; Aguilera, J.; Talavera, D.L.; Castro, M. Application and validation of algebraic methods to predict the behaviour of crystalline silicon PV modules in Mediterranean climates. Sol. Energy 2007, 81, 1396-1408. [CrossRef]

22. Sidrach-de-Cardona, M.; López, L.M. Performance analysis of a grid-connected photovoltaic system. Energy 1999, 24, 93-102. [CrossRef]

23. Muñoz, J.V.; Nofuentes, G.; Fuentes, M.; de la Casa, J.; Aguilera, J. DC energy yield prediction in large monocrystalline and polycrystalline PV plants: Time-domain integration of Osterwald's model. Energy 2016, 114, 951-960. [CrossRef] 
24. Grzesiak, W.; Mackow, P.; Maj, T.; Polak, A.; Klugman-Radziemska, E.; Zawora, S.; Drabczyk, K.; Gulkowski, S.; Grzesiak, P. Innovative system for Energy collection and management integrated within a photovoltaic module. Sol. Energy 2016, 132, 442-452. [CrossRef]

25. Zdyb, A.; Krawczak, E. The influence of external conditions on the photovoltaic modules performance. In Environmental Engineering V, 1st ed.; Pawlowska, M., Pawlowski, L., Eds.; CRC Press Taylor \& Francis Group: Boca Raton, FL, USA, 2017; pp. 261-266. ISBN 9781138031630.

26. Bora, B.; Kumar, R.; Sastry, O.S.; Prasad, B.; Mondal, S.; Tripathi, A.K. Energy rating estimation of PV module technologies for different climatic conditions. Sol. Energy 2018, 174, 901-911. [CrossRef]

27. Sharma, V.; Kumar, A.; Sastry, O.S.; Chandel, S.S. Performance assessment of different solar photovoltaic technologies under similar outdoor conditions. Energy 2013, 58, 511-518. [CrossRef]

28. Belluardo, G.; Ingenhoven, P.; Sparber, W.; Wagner, J.; Weihs, P.; Moser, D. Novel method for the improvement in the evaluation of outdoor performance loss rate in different PV technologies and comparison with two other methods. Sol. Energy 2015, 117, 139-152. [CrossRef]

29. Aste, N.; Del Pero, C.; Leonforte, F. PV technologies performance comparison in temperate climates. Sol. Energy 2014, 109, 1-10. [CrossRef]

30. Kesler, S.; Kivrak, S.; Dincer, F.; Rustemli, S.; Karaaslan, M.; Unal, E.; Erdiven, U. The analysis of PV power potential and system installation in Manavgat, Turkey-A case study in winter season. Renew. Sustain. Energy Rev. 2014, 31, 671-680. [CrossRef]

31. Dirnberger, D.; Blackburn, G.; Müler, B.; Reise, C. On the impact of solar spectral irradiance on the yield of different PV technologies. Sol. Energy Mater. Sol. Cells 2015, 132, 431-442. [CrossRef]

32. IEC 61724-1. Photovoltaic System Performance Monitoring-Guidelines for Measurement, Data Exchange, and Analysis (Part 1); Technical Report 1; International Electrotechnical Commission (IEC): Geneva, Switzerland, 2017.

33. Polo, J.; Alonso-Abella, M.; Ruiz-Arias, J.A.; Balenzategui, J.L. Worldwide analysis of spectral factors for seven photovoltaic technologies. Sol. Energy 2017, 142, 194-203. [CrossRef]

34. Mattei, M.; Notton, G.; Cristofari, C.; Muselli, M.; Poggi, P. Calculation of the polycrystalline PV module temperature using a simple method of energy balance. Renew. Energy 2016, 31, 553-567. [CrossRef]

35. Goetzberger, A.; Hebling, C. Photovoltaic materials, past, present, future. Sol. Energy Mater. Sol. Cells 2000, 62, 1-19. [CrossRef]

36. Tobias, I.; del Canizo, C.; Alonso, J. Crystalline Silicon Solar Cells and Modules. In Handbook of Photovoltaic Science and Engineering, 2nd ed.; Luque, A., Hegedus, S., Eds.; Wiley: Hoboken, NJ, USA, 2003; pp. 255-306.

37. Khana, N.A.; Rahmanb, K.S.; Aris, K.A.; Ali, A.M.; Misran, H.; Akhtaruzzaman, M.; Tiong, S.K.; Amin, N. Effect of laser annealing on thermally evaporated CdTe thin films for photovoltaic absorber application. Sol. Energy 2018, 173, 1051-1057. [CrossRef]

38. Olusol, O.I.; Madugu, M.L.; Dharmadas, I.M. Investigating the electronic properties of multi-junction ZnS/CdS/CdTe graded bandgap solar cells. Mater. Chem. Phys. 2017, 191, 145-150. [CrossRef]

39. Shafarman, W.N.; Stolt, L. Cu(InGa)Se2 solar cells. In Handbook of Photovoltaic Science and Engineering, 2nd ed.; Luque, A., Hegedus, S., Eds.; Wiley: Hoboken, NJ, USA, 2011; pp. 567-616.

40. Dupré, O.; Vaillon, R.; Green, M.A. Physics of the temperature coefficients of solar cells. Sol. Energy Mater. Sol. Cells 2015, 140, 92-100. [CrossRef]

41. Lorenzo, E.; Moretón, R.; Luque, I. Dust effects on PV array performance: In-field observations with non-uniform patterns. Prog. Photovolt. Res. Appl. 2014, 22, 666-670. [CrossRef]

42. Gulkowski, S.; Żytkowska, N.; Dragan, P. Temperature distribution analysis of different technologies of PV modules using infrared thermography. E3S Web Conf. 2018, 49, 00044. [CrossRef]

(C) 2019 by the authors. Licensee MDPI, Basel, Switzerland. This article is an open access article distributed under the terms and conditions of the Creative Commons Attribution (CC BY) license (http:/ / creativecommons.org/licenses/by/4.0/). 